\title{
PRODUKSI PIGMEN DAN IDENTIFIKASI KAPANG PENGHASILNYA MENGGUNAKAN PENDEKATAN DNA BARCODING
}

\author{
Mada Triandala Sibero ${ }^{1,2 \star}$, Kustiariyah Tarman ${ }^{3,4,}$ Ocky Karna Radjasa ${ }^{2,5,}$ Agus \\ Sabdono $^{2,5}$, Agus Trianto ${ }^{2,5,6}$, Tiara Ulfa Bachtiarini ${ }^{2,5}$ \\ ${ }^{1}$ Fakultas Perikanan dan Ilmu Kelautan, Universitas Diponegoro \\ ${ }^{2}$ Laboratorium Bioteknologi Laut Tropis, Gedung Laboratorium Kelautan dan Oseanografi Lantai 2, \\ Fakultas Perikanan dan Ilmu Kelautan, Universitas Diponegoro \\ ${ }^{3}$ Departemen Teknologi Hasil Perairan, Fakultas Perikanan dan Ilmu Kelautan, \\ Institut Pertanian Bogor \\ ${ }^{4}$ Divisi Bioteknologi Kelautan, Pusat Kajian Sumberdaya Pesisir dan Lautan, Institut Pertanian Bogor \\ ${ }^{5}$ Departemen Ilmu Kelautan, Fakultas Perikanan dan Ilmu Kelautan, Universitas Diponegoro \\ ${ }^{6}$ Laboratorium Bahan Alam Laut, Gedung UPT Laboratorium Terpadu, Universitas Diponegoro \\ Kampus Tembalang, Jalan Prof. Soedarto, SH., Semarang 50275 Jawa Tengah \\ Telepon/Fax: (024) 7460012 \\ ${ }^{\star}$ Korespondensi: madatriandala@hotmail.com \\ Diterima: 8 Februari 2018/ Disetujui: 20 April 2018
}

Cara sitasi: Sibero MT, Tarman K, Radjasa OK, Sabono A, Trianto A, Bachtiarini TU. 2018 Produksi pigmen dan identifikasi kapang penghasilnya menggunakan pendekatan DNA Barcoding. Jurnal Pengolahan Hasil Perikanan Indonesia. 21(1): 99-108.

\begin{abstract}
Abstrak
Kapang endofit laut diketahui sebagai sumber berbagai senyawa bioaktif yang berguna bagi kesehatan. Penelitian yang telah dilakukan sebelumnya membuktikan bahwa kapang endofit isolat RS3 asal tanaman pesisir Hydnophytum formicarum asal Sorong menghasilkan pigmen hitam dengan potensi sebagai fotoprotektor namun pada penelitian tersebut tidak memiliki data mengenai produksi pigmen serta identifikasi kapang penghasilnya. Penelitian ini bertujuan untuk menentukan produksi pigmen hitam asal kapang RS3 dan identifikasi kapang RS3 melalui pendekatan DNA barcoding. Kapang RS3 dikultivasi selama 30 hari menggunakan sistem statis dan sistem shaking. DNA barcoding pada identifikasi kapang RS3 menggunakan primer universal ITS1 dan ITS4 untuk mengamplifikasi wilayah internal transcribed spacer (ITS) yang menjadi conserve region pada kingdom fungi. Hasil penelitian menunjukkan bahwa kapang RS3 yang dikultivasi menggunakan sistem shaking mulai memproduksi pigmen pada hari-6 dan mencapai produksi tertinggi pada hari ke-18 $(2,42 \pm 0,03 \mathrm{mg} / \mathrm{L})$ sedangkan pada kultivasi sistem statis rendemen pigmen terbesar dihasilkan pada hari ke-30 $(2,88 \pm 0,21 \mathrm{mg} / \mathrm{L})$. Berdasarkan hasil analsis ITS rDNA diketahui bahwa kapang endofit RS3 memiliki 99\% kemiripan dengan Annulohypoxylon stygium. Kapang ini telah didaftarkan di GeneBank denga nomer akses MG605083.1.
\end{abstract}

Kata kunci: Annulohypoxylon, DNA barcoding, endofit, pigmen.

\section{Production of fungal pigment and identification of its producer through DNA barcoding approach}

\begin{abstract}
Marine endophytic fungi are known as source of various bioactive compounds that are useful for health. Previous study had demonstrated that fungus RS3 isolated as endophytic fungus of coastal plant Hydnophytum formicarum from Sorong produce black pigment with photoprotector potential. However, the study did not present data on pigment production and identification of fungus RS3 as its producer. The purposes of this research were to obtain the production data of black pigment from RS3 and identification of fungus RS3 through DNA barcoding approach. Fungus RS3 was cultivated using a static system (stand culture) and shaking system. DNA barcoding of fungus RS3 was done using the universal primers ITS1 and ITS4 to amplify the internal transcribed spacer (ITS) region. The results showed that fungus RS3 cultivated in shaking condition began producing pigments on day 6 with the highest production on the $18^{\text {th }}$ day $(2.42$ $\pm 0.03 \mathrm{mg} / \mathrm{L})$ whereas in static condition the highest pigment yield was obtained on day $30^{\text {th }}(2.88 \pm 0.21$
\end{abstract}


$\mathrm{mg} / \mathrm{L}$ ). Based on the results of ITS rDNA analysis it was known that endophytic fungus RS3 had a $99 \%$ similarity to the Annulohypoxylon stygium. This fungus had been registered in GeneBank with accession number MG605083.1.

Keyword: Annulohypoxylon, DNA barcoding, endophytic, pigment.

\section{PENDAHULUAN}

Kapang laut diketahui sebagai penghasil metabolit sekunder yang sangat prospektif dengan berbagai aktivitas biologis (Wu et al. 2016; He et al. 2017). Kapang endofit asal tumbuhan pesisir adalah salah satu jenis yang banyak dikaji (Ling et al. 2016; Cheng et al. 2017; Maciel et al. 2017; Nair et al. 2017). Beberapa peneliti berhasil mengisolasi senyawa aktif dari kapang endofit laut yang diisolasi dari berbagai tumbuhan pesisir di antaranya vaccinols $J$ dari Pestalotiopsis vaccinii dengan aktivitas sebagai anti-enterovirus (EV71), phochrodines D memiliki aktivitas sebagai antioksidan yang diisolasi dari Phomopsis sp. 33\#, kontanin dan orlandin sebagai antijamur yang diisolasi kapang Aspergillus clavatus R7 (Chen et al. 2017; Li et al. 2017; Wang et al. 2017). Hutan mangrove Indonesia menyimpan biodiversitas kapang endofit yang belum banyak dikaji. Tarman et al. (2013) berhasil mengisolasi kapang endofit asal mangrove Rhizophora mucronata dengan aktivitas antibakteri, sedangkan Abraham et al. (2016) berhasil mengisolasi kapang Emericella nidulans BPPTCC 6038 yang berpotensi sebagai bioinsektisida alami.

Kapang diketahui mampu menghasilkan metabolit sekunder lain diantaranya pigmen alami (Chadni et al. 2017; Fouillaud et al. 2017; Sarang et al. 2017). Penelitian mengenai pigmen sudah dimulai dari tahun 1957. Beberapa jenis pigmen alami yang telah dilaporkan sebagai metabolit kapang adalah cercosporin dari kapang Cercosporina Kikuchii Matsumoto et Tomoyasu; averufin dan versicolorins $A-C$ dari Aspergillus versicolor; shiraiachromes dari Shiraia bambusicola; azaphilone dari Monascus kaoliang dan melanin (Kuyama dan Tamura 1957; Hamasaki et al. 1967; Pusey dan Roberts 1963; Wu et al. 1989; Jongrungruangchok et al. 2004; Suryanarayanan et al. 2004). Melanin merupakan pigmen hasil polimerasi senyawa fenolik dan atau indolik, bersifat hidrofobik serta memiliki berat molekul yang besar. Pigmen ini dihasilkan oleh makhluk hidup lain misalnya bakteri, aktinomisetes hingga eukariota tingkat tinggi seperti manusia (Slominski et al. 2015; Radames et al. 2017).

Hasil penelitian sebelumnya telah melaporkan kapang endofit yang berhasil diisolasi dari tumbuhan epifit Hydnophytum formicarum yang berasosiasi dengan mangrove Avicennia sp. asal Sorong, Papua. Penelitian tersebut melaporkan terdapat tiga isolat kapang yang mampu menghasilkan pigmen yaitu Aspergillus versicolor RS1A MG576058 penghasil pigmen merah, RS3 penghasil pigmen hitam dan RS6A penghasil pigmen kuning belum teridentifikasi. Berdasarkan hasil karakterisasi maka diketahui bahwa kapang RS3 menghasilkan pigmen hitam yang diduga sebagai melanin dengan aktivitas biologis sebagai fotoprotektor (Sibero et al. 2016; Sibero et al. 2017). Penelitian ini bertujuan untuk menetukan produksi pigmen hitam asal kapang RS3 dan identifikasi kapang RS3 melalui pendekatan molekuler.

\section{BAHAN DAN METODE Bahan dan Alat}

Penelitian ini menggunakan isolat kapang endofit RS3 koleksi Laboratorium Mikrobiologi Hasil Perairan, Fakultas Perikanan dan Ilmu Kelautan, Institut Pertanian Bogor. Bahan yang digunakan dalah Potato Dextrose Agar (PDA) dan Potato Dextrose Broth (PDB) dari Difco ${ }^{\mathrm{TM}}$, asam klorida ( $\mathrm{HCl})$ 0,1 N, pencucian ekstrak kasar pigmen menggunakan pelarut organik dari Merk, primer (Macrogen), GoTaq Green Master Mix (Promega) dan agarose dari (Promega). Alat yang digunakan adalah autoclave HVE50 (Amerex Instruments), mikrosentrifugator (Eppendorf), petri dish (Pyrex) dan labu 
Erlenmayer (Duran) ukuran $250 \mathrm{~mL}$, shaker (Corning ${ }^{\oplus}$ SE), $\mathrm{pH}$ meter (EcoTest pH2 Waterproof Pocket Tester), kertas saring (Macherey-Nagel 640d.Ø $1125 \mathrm{~mm}$ ), PCR (BioRad T100 Thermal Cycler), elektroforesis (Cleaver Scientific Ltd.), dan gel documentation menggunakan UVITEC Cambridge dan heating block (Thermo Scientific).

\section{Metode Penelitian \\ Ekstraksi Pigmen}

Pigmen diekstrak dengan metode pengendapan menggunakan asam klorida $(\mathrm{HCl}) 0.1 \mathrm{~N}$ yang diteteskan secara perlahan. Pigmen yang mengendap selanjutnya dipisahkan menggunakan sentrifugator dengan kecepatan $5000 \mathrm{~g}$ selama 15 menit dengan suhu $4^{\circ} \mathrm{C}$. Endapan pigmen selanjutnya dicuci menggunakan pelarut organik (kloroform, etil asetat dan metanol) selanjutnya dikeringkan menggunakan gas nitrogen dingin (Sibero et al. 2016). Bobot melanin ditimbang untuk memperoleh rendemen pigmen.

\section{Produksi Pigmen Kapang}

Kapang dikultur pada $150 \mathrm{~mL}$ media PDB selama 30 hari dengan perlakukan statis dan agitasi menggunakan shaker dengan kecepatan 119 r.p.m. pada suhu $27^{\circ} \mathrm{C}$. Bobot miselia kapang dan perubahan warna media koleksi diamati setiap tiga hari. Pengukuran bobot miselia dilakukan dengan cara memisahkan miselia menggunakan kertas saring (Advantec 7, Ø $125 \mathrm{~mm}$ ) yang telah dikeringkan di dalam desikator selama 24 jam dan bobotnya ditimbang. Kertas saring yang berisi miselia kapang dikeringkan di dalam desikator selama 48 jam dan ditimbang. Bobot miselia diperoleh dengan cara pengurangan bobot kertas saring yang berisi miselia terhadap bobot kertas saring kosong (Indarmawan et al. 2016). Bobot kering miselia selanjutnya diolah untuk mendapatkan kurva pertumbuhan.

\section{Identifikasi Molekuler}

Ekstraksi DNA

Kapang RS3 dikultivasi pada media PDA selama 7 hari. Miselum kapang diambil dan direndap di dalam larutan $0,5 \%$ saponin dalam PBS dan $100 \mu \mathrm{L}$ ddH $_{2} \mathrm{O}$ selama 24 jam di dalam lemari pendingin $\left(4^{\circ} \mathrm{C}\right)$. Larutan yang berisi miselium selanjutnya diagitasi menggunakan vortex dan disentrifugasi dengan kecepatan $12.000 \mathrm{rpm}$ selama 10 menit. Filtrat hasil sentrifugasi dibuang lalu $100 \mu \mathrm{L}$ ddH $\neg 2 \mathrm{O}$ ditambahkan dan agitasi menggunakan vortex selama 30 detik dan disentrifugasi kembali dengan kecepatan dan waktu yang sama. Filtrat kembali dibuang lalu $50 \mu \mathrm{L}$ 20\% Chelex 100 ditambahkan ke dalam pelet dan dipanaskan menggunakan heating block selama 5 menit dengan suhu $85^{\circ} \mathrm{C}$ lalu diagitasi menggunakan vortex selama 15 detik dan dipanaskan dengan suhu dan waktu yang sama. Sampel selanjutnya diagitasi kembali selama 15 detik lalu disentrifugasi selama 15 menit dengan kecepatan $12.000 \mathrm{rpm}$. Filtrat yang diperoleh selanjutnya dipindahkan ke dalam tube yang baru untuk digunakan pada amplifikasi DNA (Sibero et al. 2017).

\section{Amplifikasi DNA}

DNA kapang RS3 diamplifikasi menggunakan polymerase chain reaction (PCR). Komposisi PCR Mix yang digunakan adalah 12,5 $\mu \mathrm{L}$ GoTaq Green Master Mix, 1 $\mu \mathrm{L}$ primer ITS1 (5'-TCC GTA GGT GAA CCT GCG G-3'), $1 \mu \mathrm{L}$ primer ITS4 (5'-TCC TCC GCT TAT TGA TAT GC-3'), $0.5 \mu \mathrm{L}$ DNA template dan $10 \mu \mathrm{L}$ ddH2O. Kondisi PCR yang digunakan yaitu: denaturasi pada suhu $95^{\circ} \mathrm{C}$ selama 1 menit, annealing pada suhu $55^{\circ} \mathrm{C}$ selama 1 menit dan extention pada suhu $72^{\circ} \mathrm{C}$ selama 1 menit dan extention akhir selama 7 menit dengan suhu yang sama. Tahapan denaturasi, annealing dan extention dilakukan sebanyak 30 siklus. Hasil PCR selanjutnya dielektroforesis untuk mengetahui keberhasilan perbanyakan DNA secara in vitro dan hasilnya divisualisasi menggunakan UVIDocHD5 (UVITECH Cambridge). Produk PCR yang berhasil diamplifikasi selanjutnya dikirim ke $1^{\text {st }}$ Base Laboratories Sdn Bhd, Malaysia untuk disekuensing. Hasil sekuensing selanjutnya dianalisis menggunakan Basic Local Alignment Search Tool (BLAST) sedangkan pohon filogenetiknya disusun menggunakan software MEGA 7.0 package dengan metode neighbor-joining dengan 1000 kalipengulangan 
bootstrap (Sibero et al. 2017).

\section{Analisis Data}

Seluruh data diolah menggunakan Predictive Analytic Software (PASW) Statistic 18 package dengan metode One Way ANOVA dengan tingkat kepercayaan $95 \%(P<0.05)$. Uji lanjut dilakukan dengan metode Duncan.

\section{HASIL DAN PEMBAHASAN Produksi Pigmen oleh Kapang RS3}

Kurva pertumbuhan kapang RS3 dari hasil perlakuan ini dapat dilihat pada Gambar 1. Berdasarkan hasil pengukuran biomassa miselium kapang RS3, diketahui bahwa kapang yang dikultivasi menggunakan agitasi dengan shaker menghasilkan biomassa yang lebih tinggi dibandingkan kapang yang dikultivasi dengan sistem statis (Gambar 1). Kapang yang dikultivasi dengan sistem statis hanya tumbuh menutupi permukaan media. Hal ini menunjukkan bahwa kapang RS3 memiliki area pertumbuhan yang terbatas sedangkan miselium kapang RS3 yang dikultivasi dengan agitasi tumbuh membentuk bola miselum dengan berbagai ukuran yang tumbuh dan memenuhi seluruh media (Gambar 2).

Pertumbuhan kapang dengan sistem

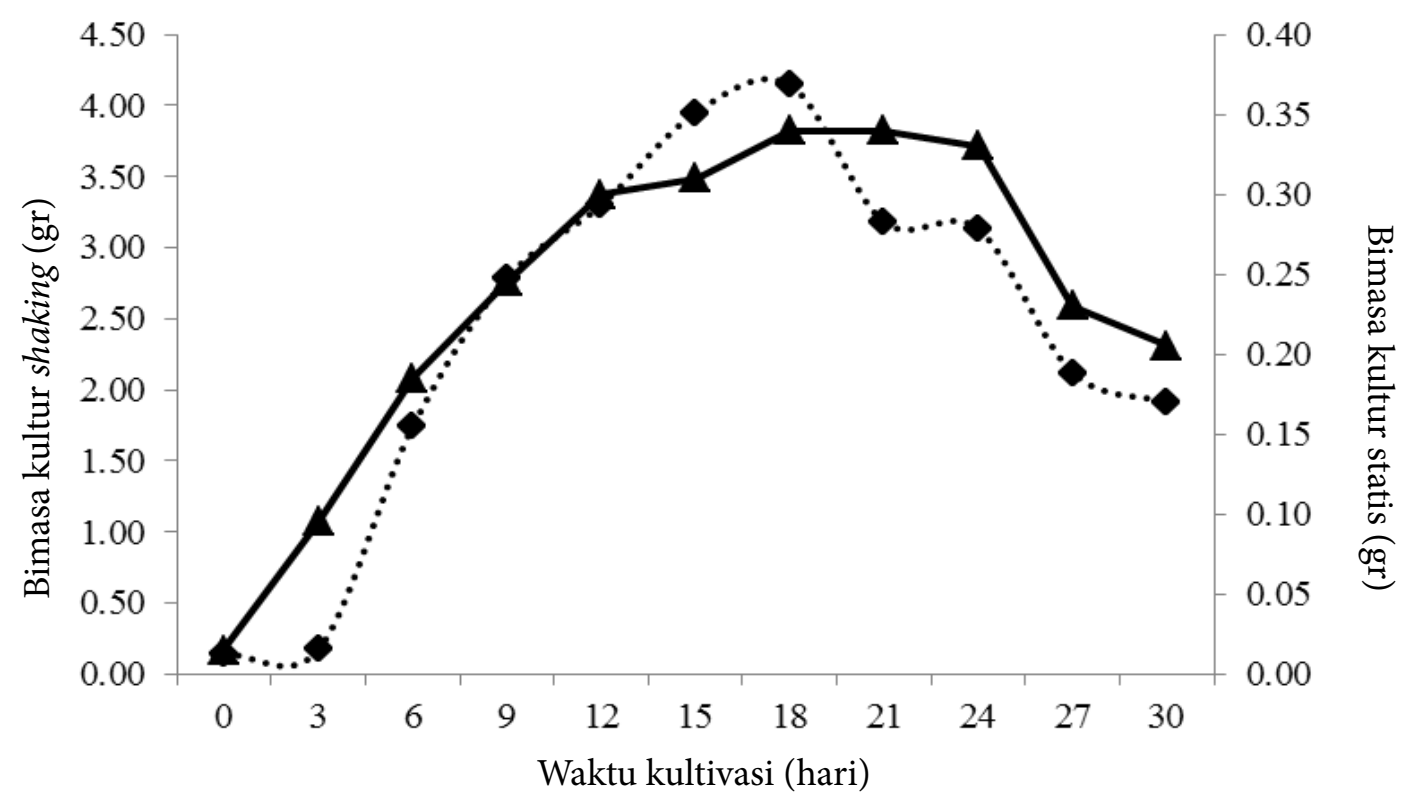

Gambar 1. Kurva pertumbuhan kapang RS3 pada perlakuan agitasi yang berbeda

( $\rightarrow$ biomassa kultur statis; - biomassa kultur shaking)

(Figure 1 RS3 mold growth curve on different agitation treatments: (_- ) static biomass culture, shaking culture biomass).

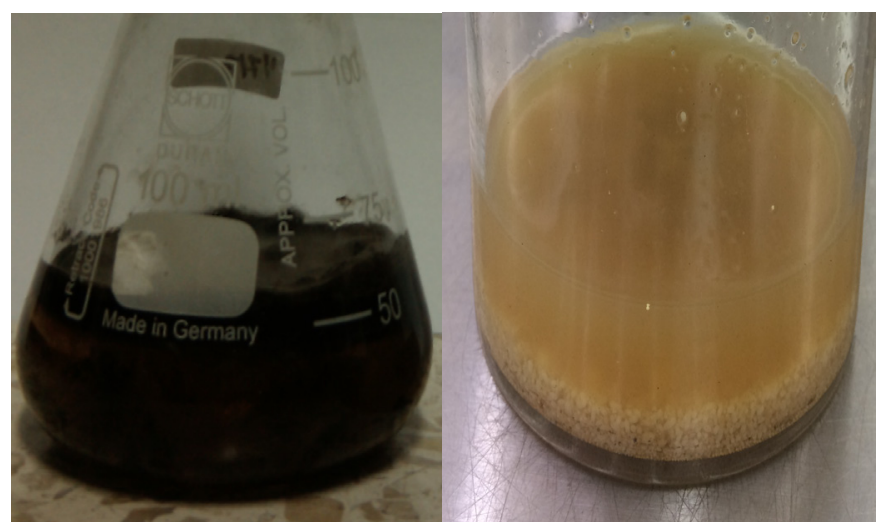

Gambar 2. Bentuk miselium kapang RS3 pada sistem kultivasi yang berbeda (a. sistem statis usia 15 hari, b. sistem shaking usia 3 hari)

(Figure 2 RS3 mold shell miselium in different cultivation systems ( 15 day static system, $b$ a 3 day shaking system)). 
statis menunjukkan fase pertumbuhan pada hari ke-0 hingga hari ke-18 kemudian mengalami fase stasioner pada hari ke-18 hingga hari ke-21 dan fase kematian pada hari ke-21 hingga hari ke-30. Kapang RS3 yang dikultivasi pada kondisi shaking melalui fase adaptasi pada hari ke-0 hingga hari ke-3, fase pertumbuhan pada hari ke-3 hingga hari ke-15, fase stasioner pada hari ke-15 hingga hari ke-18 dan mengalami fase kematian dari hari ke-18 hingga hari ke-30 (Gambar 1). Data menunjukkan bahwa kapang yang dikultivasi pada sistem shaking mengalami fase kematian yang lebih cepat dibandingkan kapang yang dikultivasi pada sistem statis. Szilágyi et al. (2013) menyatakan bahwa fase kematian diakibatkan oleh habisnya nutrisi pada media kultivasi sehingga jumlah sel yang mati lebih banyak dibandingkan dengan jumlah sel yang tumbuh dan hidup. Sumber karbon merupakan nutrisi penting pada pertumbuhan mikroorganisme termasuk kapang. Jumlah karbon pada media akan berkurang setelah melalui fase eksponensial akibat konsumsi selama masa pertumbuhan sehingga mengakibatkan kematian sel. Kapang RS3 yang dikultivasi dengan sistem shaking menghasilkan miselium yang lebih banyak dibandingkan sistem statis sehingga jumlah sel yang memanfaatkan karbon semakin besar dan menyebabkan penurunan jumlah karbon yang lebih cepat. Fenomena ini secara langsung menyebabkan kematian sel yang lebih cepat dibandingkan kapang yang dikultivasi dengan sistem statis. Dextrose diketahui sebagai sumber karbon terbaik untuk produksi melanin dan biomassa pada kapang Aspergilus fumigatus AFGRD105 (Raman et al. 2015). Andikawati et al. (2014) yang melakukan penelitian serupa melaporkan bahwa kapang EN2 melewati fase stasioner hingga hari ke-21 sedangkan kapang TP6 yang endofit TP6 yang dikultivasi dengan sistem shaking juga mulai memasuki fase kematian pada hari ke-18 (Ukhty et al. 2017). Produksi pigmen hitam dapat dilihat pada Tabel 1. Kapang RS3 yang dikultivasi pada sistem yang berbeda menunjukkan produksi pigmen yang berbeda pula. Kapang yang dikultivasi pada sistem shaking mulai menghasilkan pigmen pada hari kultivasi ke-6 sedangkan kapang yang dikultur dengan sistem statis mulai menghasilkan pigmen pada hari ke-15 (Tabel 1).

Data pada Tabel 1 menunjukkan bahwa kapang RS3 yang dikultivasi pada sistem statis mulai menghasilkan pigmen pada hari ke-15 dan terus meningkat hingga hari ke-27 lalu mencapai produksi konstan setelah mencapai usia 27 hari sedangkan pada kapang yang dikultur dengan sistem shaking memproduksi pigmen dari hari ke-6 kemudian terus

Tabel 1 Rendemen pigmen kapang RS3 pada sistem kultivasi yang berbeda (Table 1 Yield of RS3 pigment in different cultivation systems)

\begin{tabular}{ccc}
\hline \multirow{2}{*}{ Hari ke- } & \multicolumn{2}{c}{ Produksi pigmen $(\mathrm{mg} / \mathrm{L})$} \\
\cline { 2 - 3 } & Statis & Shaking \\
\hline 0 & $0.00 \pm 0.00$ & $0.00 \pm 0.00$ \\
3 & $0.00 \pm 0.00$ & $0.00 \pm 0.00$ \\
6 & $0.00 \pm 0.00$ & $0.19 \pm 0.02^{\mathrm{a}}$ \\
9 & $0.00 \pm 0.00$ & $1.24 \pm 0.01^{\mathrm{b}}$ \\
12 & $0.00 \pm 0.00$ & $1.46 \pm 0.01^{\mathrm{c}}$ \\
15 & $0.41 \pm 0.19^{\mathrm{a}}$ & $2.10 \pm 0.03^{\mathrm{d}}$ \\
18 & $0.55 \pm 0.22^{\mathrm{b}}$ & $2.42 \pm 0.03^{\mathrm{e}}$ \\
21 & $1.72 \pm 0.27^{\mathrm{c}}$ & $1.80 \pm 0.04^{\mathrm{f}}$ \\
24 & $1.80 \pm 0.41^{\mathrm{c}}$ & $1.75 \pm 0.04^{\mathrm{f}}$ \\
27 & $2.85 \pm 0.35^{\mathrm{d}}$ & $1.13 \pm 0.02^{\mathrm{g}}$ \\
30 & $2.88 \pm 0.21^{\mathrm{d}}$ & $1.13 \pm 0.01^{\mathrm{g}}$ \\
\hline
\end{tabular}


bertambah hingga hari ke-18 dan mengalami penurunan pada hari ke-21 hingga hari ke30. Kapang RS3 menghasilkan rendemen pigmen terbesar pada hari ke-30 pada sistem kultivasi statis. Rendemen pigmen yang dihasilkan sistem kultivasi statis pada hari ke-27 $(2,85 \pm 0,35 \mathrm{mg} / \mathrm{L})$ tidak berbeda nyata dengan rendemen yang dihasilka pada hari ke-30 $(2,88 \pm 0,21 \mathrm{mg} / \mathrm{L})$ sehingga pada sistem statis kultivasi selama 27 hari dianggap sebagai waktu terbaik untuk mendapatkan rendemen optimal sedangkan pada kultivasi sistem shaking dapat terlihat bahwa rendemen tertinggi dihasilkan oleh hasil kultivasi 18 hari $(2,42 \pm 0,03 \mathrm{mg} / \mathrm{L})$ dan terus menurun hingga hari ke-30 $(\mathrm{P}<0.05)$. Rendemen pada hari ke 18 berbeda nyata dengan perlakuan lainnya $(P<0.05)$ sehingga waktu kultivasi selama 18 hari dianggap sebagai waktu optimal untuk produksi pigmen dengan sistem shaking. Zou dan Ma (2017) melaporkan bahwa jamur Auricularia auricula yang dikultivasi dengan sistem shaking selama 8 hari menghasilkan rendemen terbesar pada hari ke-7. Penelitian lain menunjukkan bahwa kapang $A$. fumigatus AFGRD105 menghasilkan rendemen melanin yang stabil setelah hari ke-5 (Rama et al. 2015) sehingga dapat disimpulkan bahwa produksi pigmen melanin pada setiap organisme tergantung pada berbagai kondisi termasuk spesiesnya.

\section{Identifikasi molekuler kapang RS3}

Kapang RS3 merupakan kapang endofit asal tumbuhan epifit $H$. formicarum yang diisolasi dengan metode sterilisasi permukaan
(Sibero et al. 2017). Pemilihan kapang ini sebagai sumber melanin berdasarkan kemampuannya merubah warna media agar PDA menjadi hitam setelah usia kultivasi 10 hari. Penelitian sebelumnya tidak melakukan identifikasi spesies kapang RS3 sebagai sumber pigmen melanin dengan potensi sebagai foto protektor (Sibero et al. 2016). Penelitian ini menggunakan pendekatan molekuler untuk mengidentifikasi spesies kapang RS3 dengan metode DNA barcoding. DNA barcoding merupakan metode populer yang digunakan untuk mengidentifikasi spesies organisme yang sulit untuk diidentifikasi karena memiliki kemiripan yang sangat besar antar individu (cryptic species). Kingdom fungi secara umum dan mikro-fungi khususnya memiliki kemiripan yang sangat besar antar spesies pada genus yang sama sehingga aplikasi DNA barcoding sangat disarankan untuk mengidentifikasi spesiesnya (Xu 2016). Tahun 2012, International Fungal Barcoding Consortium memutuskan wilayah internal transcribed spacer (ITS) yang merupakan bagian dari nuclear ribosomal RNA gene cluster sebagai wilayah yang digunakan sebagai marker dalam DNA barcoding spesies untuk kingdom fungi (Schoch et al. 2012). Amplifikasi DNA pada wilayah ITS dapat menggunakan beberapa pilihan primer. Penelitian ini menggunakan primer ITS1 sebagai forward dan ITS4 sebagai reverse primer. Primer ini akan mengamplifikasi DNA jamur yang terletak di lokus ITS yang menjadi wilayah konservatif untuk kingdom fungi (Schoch et al. 2012). Letak lokus ini

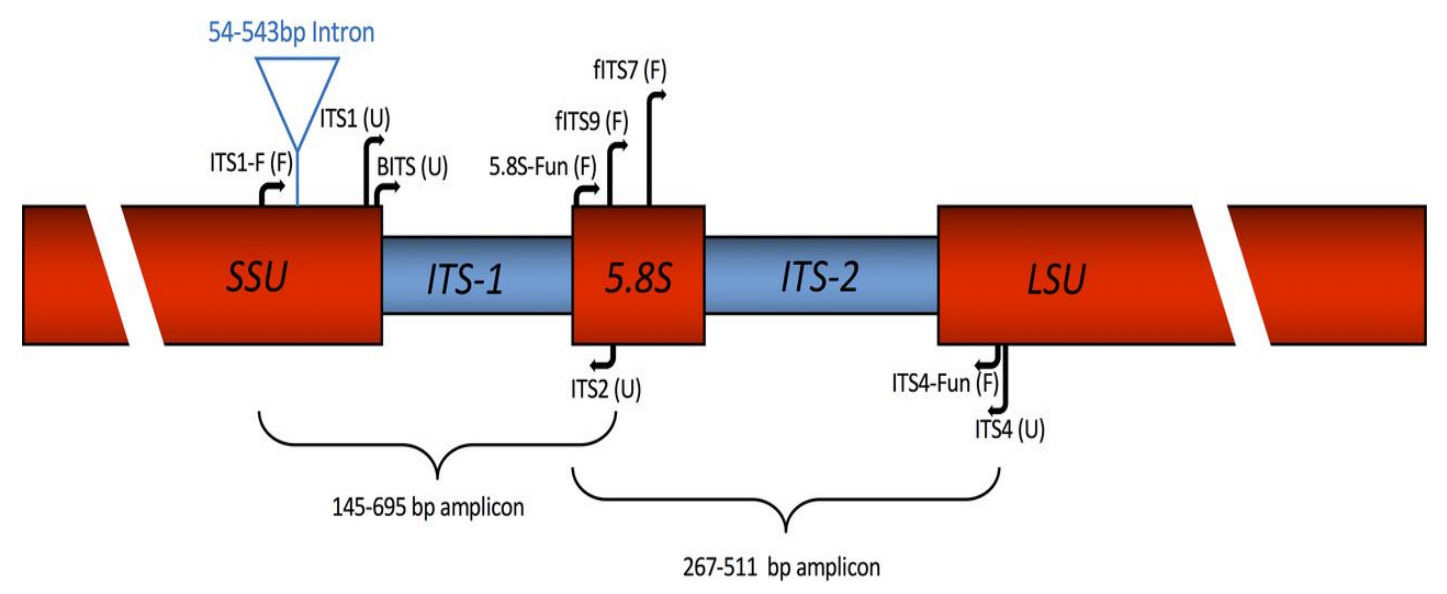

Gambar 3. Letak wilayah amplifikasi primer ITS (Sumber: Taylor et al. 2016)

(Figure 3. Location of ITS primary amplification region (Source: Taylor et al. 2016)). 
diperlihatkan oleh Gambar 3. Kualitas hasil amplifikasi DNA kapang RS3 diperiksa menggunakan gel electrophoresis.

Hasil amplifikasi DNA dan visualisasi produk PCR diketahui bahwa panjang DNA kapang RS3 yang diamplifikasi menggunakan primer ITS1 dan ITS4 adalah 682 bp. Primer ITS1 dan ITS4 diketahui akan mengamplifikasi DNA dengan panjang < 700 bp (Roca et al. 2003). Hasil sequencing selanjutnya digunakan untuk pencarian spesies kapang RS3 menggunakan BLAST. Hasil identifikasi menggunakan DNA barcoding membuktikan bahwa kapang RS3 merupakan homolog dari Annulohypoxylon stygium strain DR47 dengan tingkat similaritas 99\%. Kapang A. stygium RS3 didaftarkan pada GeneBank dengan nomer akses MG605083.1. Hasil ini digunakan dalam rekonstruksi pohon filogenetik yang ditampilkan oleh Gambar 4. Berdasarkan kladiogram pada Gambar 4 terlihat bahwa kapang RS3 memiliki kemiripan secara genetik dengan A. stygium KC311843.1. Berdasarkan hasil penelusuran pustaka mengenai spesies A. stygium maka diketahui bahwa jamur ini telah terdaftar pada Mycobank dengan nomer akses MB500326. Jamur ini masuk di divisio ascomycota ordo xylariales famili hyoxylaceae dan genus Annulohypoxylon (Mycobank 2016). Hsieh et al. (2005) menyatakan bahwa
A. stygium memiliki sinonim Hypoxylon stygium. Passarini et al. (2013) melaporkan A. stygium sebagai kapang asosiasi spons Dragmacidon reticulatum. Kapang ini juga pernah dilaporkan sebagai endofit yang memproduksi senyawa annulostygilactone dengan aktivitas sebagai inhibitor nitrit oksida (NO) (Cheng et al. 2014). Laporan yang masuk hingga 2017, sebanyak 24 senyawa yang diisolasi dari genus Annulohypoxylon. Berdasarkan hasil penelitian sebelumnya, A. stygium pernah diisolasi sebagai kapang asosiasi pada alga Bostrychia radicans. Penelitian ini berhasil mengisolasi senyawa 3-benzylidene-2-methylhexahydropyrrolo [1,2- $\alpha]$ pyrazine-1,4-dione (1) dan 1-(1,3-Benzodioxol-5-yl)-1,2-propanediol (2) (Gambar 5), senyawa ini terbukti memiliki kemampuan fotoprotektor (Maciel et al. 2017). Hasil penelitian tersebut mendukung hasil penelitian Sibero et al. (2016) yang juga membuktikan bahwa pigmen dari kapang A. stygium RS3 memiliki kemampuan sebagai fotoprotektor.

\section{KESIMPULAN}

Berdasarkan hasil penelitian diketahui bahwa kapang RS3 yang dikultivasi menggunakan sistem shaking mulai memproduksi pigmen pada hari-6 dan

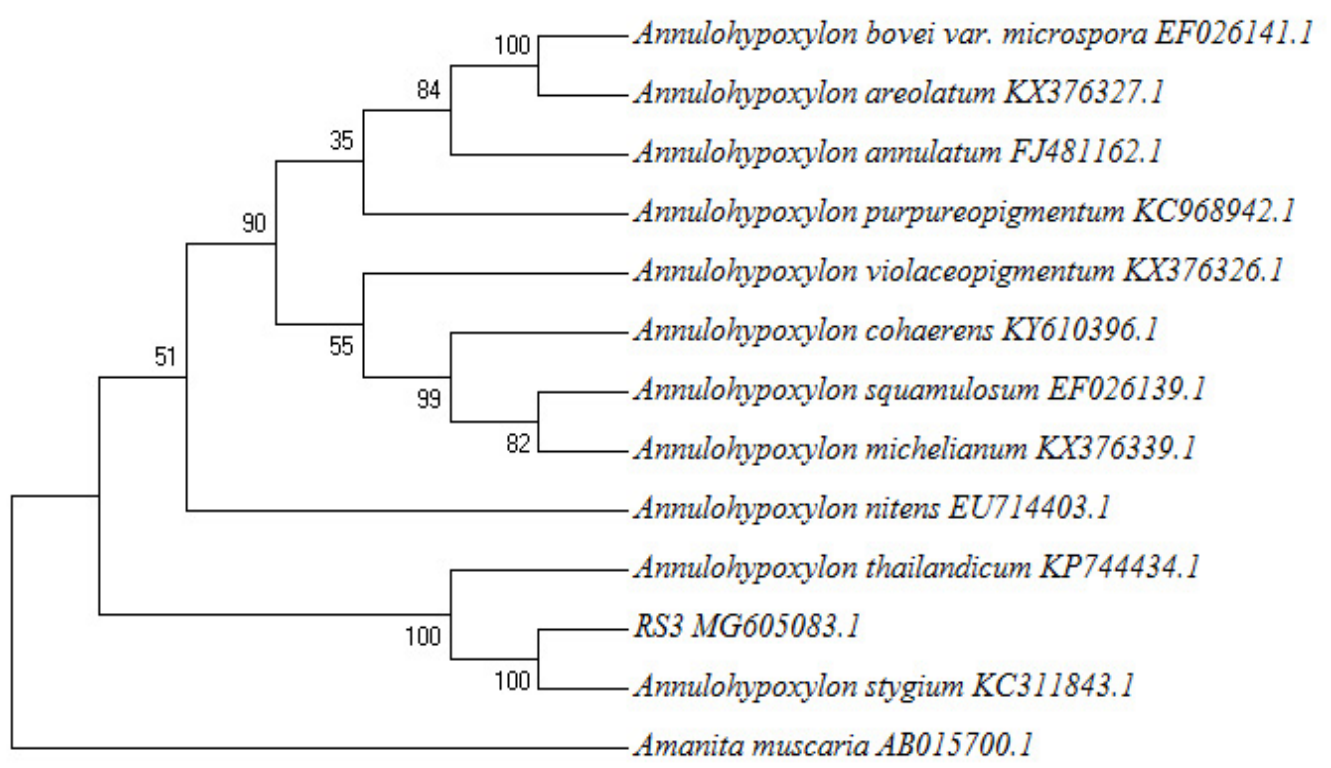

Gambar 4 Kladiogram pohon filogenetik kapang RS3 dari hasil analisis rDNA wilayah ITS kapang RS3 (Sumber: Taylor et al. 2016)

(Figure 4 Cladiogram of RS3 phylogenetic tree from rDNA analysis of ITS area of RS3 mold). 


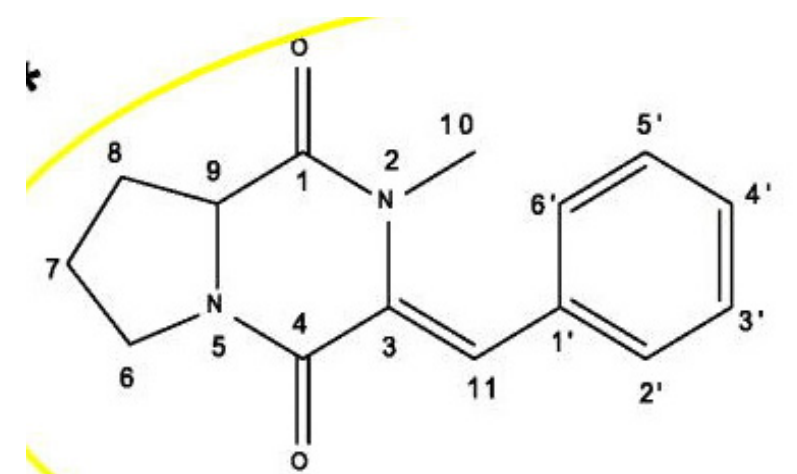

Compound 1

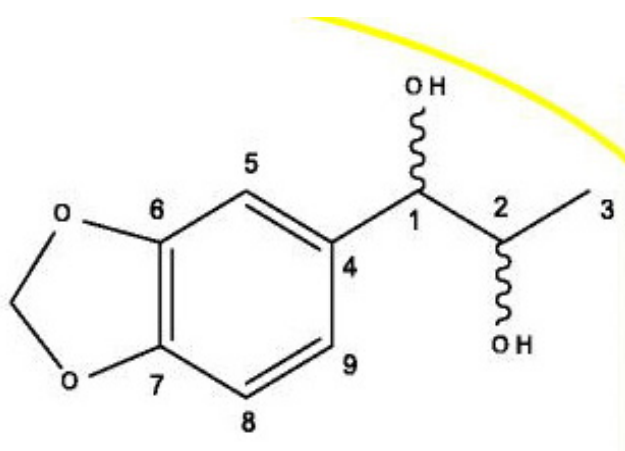

Compound 2

Gambar 5. Senyawa fotoprotektor dari A. stygium (Sumber: Maciel et al. 2017)

(Figure 5 Photoprotektor compounds of A. stygium (Source: Maciel et al. 2017))

mencapai produksi tertinggi pada hari ke-18 $(2,42 \pm 0,03 \mathrm{mg} / \mathrm{L})$ sedangkan pada kultivasi sistem statis rendemen pigmen terbesar dihasilkan pada hari ke-30 $(2,88 \pm 0,21 \mathrm{mg} / \mathrm{L})$. Berdasarkan hasil analsis ITS rDNA diketahui bahwa kapang endofit RS3 memiliki 99\% kemiripan dengan Annulohypoxylon stygium. Kapang ini telah didaftarkan di GeneBank denga nomer akses MG605083.1.

\section{UCAPAN TERIMA KASIH}

Penulis mengucapkan terima kasih kepada Kementerian Riset, Teknologi dan Pendidikan Tinggi yang telah mendanai sebagian dari penelitian ini menggunakan skema Program Magister Menuju Doktor Bagi Sarjana Unggulan (PMDSU), tahun anggaran 2017, No: 315-08/UN7.5.1/PP/2017.

\section{DAFTAR PUSTAKA}

Abraham S, Basukriadi A, Pawiroharsono S, Sjamsuridzal W. 2016. The potency of active from mangrove endophyte Emericella nidulans BPPTCC 6038 as bioinsecticide. American Institute of Physics Conference Proceedings. 1729(1).

Andikawati A, Oktavia Y, Ibrahim B, Tarman K. 2014. Isolasi dan penapisan kapang laut endofit penghasil selulase. Jurnal Ilmu dan Teknologi Kelautan Tropis. 6(1): 219-227.

Chadni Z, Rahaman MH, Jerin I, Hoque KMF, Reza MA. 2017. Extraction and optimisation of red pigment production as secondary metabolites from Talaromyces verruculosus and its potential use in textile industries. Mycology. 8(1): 48-57.

Chen $\mathrm{H}$, Huang $\mathrm{M}$, Li X, Liu L, Chen B, Wang J, Lin Y. 2017. Phochrodines A-D, first naturally occurring new chromenopyridines from mangrove entophytic fungus Phomopsis sp. 33\#. Fitoterapia.

Cheng MJ, Wu MD, Chen JJ, Cheng YC, Hsieh MT, Hsieh SY, Yuan GF, Su YS. 2014.Secondary metabolites from the endophytic fungus Annulohypoxylon stygium BCRC 34024. Chemistry of Natural Compounds. 50(2): 237-241.

Cheng YB, Lu YY, Chang FR, Wang SW, Chen CY, Wu YC. 2017. Anti-angiogenic diketopiperazines from the endophytic fungus Duaporthe arecae associated with mangrove Kandelia obovate. Planta Medica International Open 4(S01).

Fouillaud M, Venkatachalam M, Llorente M, Magalon H, Cuet P, Defossé L. 2017. Biodiversity of pigmented fungi isolated from marine environment in La Réunion Island, Indian Ocean: new resources for colored metabolites. Journal of Fungi. 3(3).

Hamasaki T, Hatsuda Y, Terashima N, Renbutsu M. 1967. Studies on the metabolites of Aspergillus versicolor (Vuillemin) Tiraboschi. Agricultural and Biological Chemistry. 31(1): 11-17.

He H, Ma Z, Wang Q, Liu Y, Xu H. 2017. Chemical constituents of the mangroveassociated fungus Capnodium sp. SZF22. A new eremophilane sesquiterpene. Natural Product Research 30(13): 1526- 
1531.

Jongrungruangchok S, Kittakoop P, Yongsmith B, Bavovada R, Tanasupawat S, Lartpornmatulee N, Thebtaranonth Y. 2004. Azaphilone pigments from a yellow mutant of the fungus Monascus kaoliang. Phytochemistry. 65(18): 2569-2575.

Kuyama S, Tamura T. 1957. Cercosporin. A pigment of Cercosporina Kikuchii Matsumoto et Tomoyasu. I. Cultivation of fungus, isolation and purification of pigment. Journal of The American Chemical Society. 79(21): 5725-5726.

Li W, Xiong P, Zheng W, Zhu X, She Z, Ding W, Li C. 2017. Identification and antifungal activity of compounds from the mangrove endophytic fungus Aspergillus clavatus R7. Marine Drugs. 15(8).

Ling OM, Teen LP. Mujahid A, Proksch P, Muller M. 2016. Initial screening of mangrove endophytic fungi for antimicrobial compounds and heavy metal biosorption potential. Sains Malaysiana. 45(7): 1063-1071.

Maciel OMC, Tavares RSN, Caluz DRE, Gaspar LR, Debonsi HM. 2017. Photoprotective potential of metabolites isolated from algae-associated fungi Annulohypoxylon stygium. Journal of Photochemistry and Photobiology. 178: 316-322.

Mycobank. 2016. Annulohypoxylon stygium. Dapat diakses pada: http://www. mycobank.org/BioloMICS.

Nair CN, Goveas S, D'Souza L, D'Cunha F, D'Souza V. 2017. 2017. Antibacterial and antioxidant potential of organic solvents extract of mangrove endophytic fungus Eupenicillium senticosum Scott. Journal of Alternative Medicine Research. 9(1): 6573.

passarini MRZ, Santos C, Lima N, Berlinck RGS, Sette LD. 2013. Filamentous fungi from the Atlantic marine sponge Dragmacidon reticulatum. Archives of Microbiology. 195(2): 99-111.

Pusey DFG, Roberts JC. 1963. Studies in mycological chemistry. Part XIII. Averufin, a red pigment from Aspergillus versicolor(Vuillemin) Tiraboschi. Journal of Chemical Society. 0: 3542-3547.
Radames JBC, Vij R, Casadevall A. 2017. Microbial melanins for radioprotection and bioremediation. Microbial Biotechnology. 10(5): 1186-1190.

Raman NM, Shah PH, Mohan M, Ramasamy S. 2015. Improved production of melanin from Aspergillus fumigatus AFGRD105 by optimation of media factors. $A M B$ Express. 5: 72.

Roca MG, Davide LC, Wheals AE. 2003. Template preparation for rapid PCR in Colletotrichum lindemuthianum. Brazilian Journal of Microbiology. 34: 8-12.

Sarang HS, Rajani P, Vasanthakumari MM, Kumara PM, Siva R, Ravikanth G, Shaanker RU. 2017. An endophytic fungus, Gibberella moniliformis from Lawsonia inermis L. produces lawsone, an orange-red pigment. Antonie van Leeuwenhoek. 110(7): 853-862.

Sibero MT, Sahara R, Syafiqoh N, Tarman K. 2017. Antibacterial activity of red pigment isolated from coastal endophytic fungi against multidrug resistant bacteria. Biotropia. 24(2): 161-172.

Sibero MT, Tarman K, Hanif N. 2016. Karakterisasi dan aktivitas fotoprotektor pigmen kapang endofit asal tumbuhan pesisir sarang semut (Hydnophytum formicarum). Jurnal Pengolahan Hasil Perikanan Indonesia. 19(1): 1-8.

Schoch CL, Seifert KA, Huhndorf S, Robert V, Spouge JL, Levesque CA, Chen W, Consortium FB. 2012. Nuclear ribosomal internal transcribed spacer (ITS) region as a universal DNA barcode marker for fungi. Proceeding of The National Academy of Sciences. 109(16): 6241-6246.

Slominski RM, Zmijewski MA, Slominski AT. 2015. The role of melanin pigment in melanoma. Experimental Dermatology. 24(4): 258-259.

Suryanarayanan TS, Ravishankar JP, Venkatesan G, Murali TS. 2004. Characterization of the melanin pigment of a cosmopolitan fungal endophyte. Mycological Research. 108(8): 974-978.

Szilágyi M, Miskei M, Karányi Z, Lenkey B, Pocsi, Emri T. 2013. Transcriptome 
changes initiated by carbon starvation in Aspergillus nidulans. Microbiology. 159: 176-190.

Taylor DL, Walters WA, Lennon NJ, Bochicchio J, Krohn A, Caporaso JG, Pennanen T. Accurate estimation of fungal biodiversity and abundance through improved lineage-specific primers optimized for illumina amplicon sequencing. Applied and Environmental Microbiology 82(24): 7217-7226.

Ukhty N, Tarman K, Setyaningsih I. 2017. Isolation of endophytic fungi from the coastal plant terong pungo (Solanum sp.) and its antibacterial activity against oral pathogenic bacteria. Biotropia. 24(1): 9-15.

Wang JF, Liang R, Liao SR, Yang B, Tu ZC, Lin XP, Wang BG, liu Y. 2017. Vaccinols J-S, ten new salicyloid derivatives from the marine mangrove-derived endophytic fungus Pestalotiopsis vaccinii. Fitoterapia. 120: 164-170.

Wu C, Zhao Y, Chen R, Liu D, Liu M, Proksch P, Guo P, Lin W. 2016. Phenolic metabolites from manrove-associated Penicillium pinophilum fungus with lipid-lowering effects. Royal Society of Chemistry Advance. 6: 21969-21978.

Wu H, Lao XF, Wang QW, Lu RR, Shen C, Zhang F, Liu M, Jia L. 1989. The shiraiachromes: novel fungal perylenequinone pigments from Shiraia bambusicola. Journal of Natural Product. 52(5): 948-951.

$\mathrm{Xu}$ J. 2016. Fungal barcoding. NRC Research Press. 59: 913-932.

Zou Y, Ma K. 2017. Screening of Auricularia auricula strains for strong production ability of melanin pigments. Food Science and Technology. 38(1): 41-44. 